\title{
STRATEGI PENINGKATAN LINGKUNGAN SEKOLAH PADA SEKOLAH DASAR ISLAM AL-IKHLAS JAKARTA SELATAN
}

\author{
Fathudin Ali ${ }^{1}$, Deni Darmawan ${ }^{2}$ \\ Dosen Fakultas Ekonomi, Universitas Pamulang Tangerang Selatan \\ dosen01821@unpam.ac.id ${ }^{1}$,dosen01723@unpam.ac.id ${ }^{2}$
}

\begin{abstract}
ABSTRAK
Sekolah dasar Islam Al-Ikhlas merupakan satuan unit dari Yayasan Masji Al-Ikhlas (YMAI) yang terus mengalami peningkatan baik dari pembelajaran, jumlah siswa dan sarana prasarana. Tujuan penelitian ini ingin mengetahui bagaimana strategi peningkatan lingkungan sekolah di sekolah dasar Islam Al-Ikhlas Jakarta Selatan. Metode penelitian ini dilakukan dengan pendekatan kualitatif deskriptif untuk memahami fenomena tentang sesuatu hal yang dialami oleh subjek penelitian dan mendeskripsikan dalam bentuk bahasa dan kata-kata. Teknik pengumpulan data dengan pengamatan, wawancara, dan dokumentasi. Hasil dari penelitian ini bahwa strategi peningkatan lingkungan sekolah di SD Islam Al-ikhlas secara internal yaitu kepemimpinan, sumber daya manusia, kurikulum dan kegiatan belajar mengajar (KBM) dan keuangan. Sedangkan strategi peningkatan lingkungan secara eksternal melalui peningkatan peran orang tua/masyarakat, peningkatan teknologi dan kebijakan pemerintah.
\end{abstract}

Kata Kunci :Strategi, peningkatan, lingkungan sekolah

\begin{abstract}
The Al-Ikhlas Islamic Primary School is a unit of the Masjid Al-Ikhlas Foundation (YMAI) which continues to experience an increase in both learnings, the number of students, and infrastructure. The purpose of this research is to find out how the strategy for improving the school environment in Islamic elementary school Al-Ikhlas, South Jakarta. This research method is carried out with a descriptive qualitative approach to understand the phenomenon of something experienced by the research subject and describe it in the form of language and words. Data collection techniques by observation, interviews, and documentation. The results of this study indicate that the internal strategies for improving the school environment at AlIkhlas Islamic Elementary School are leadership, human resources, curriculum and teaching, and learning activities, and finance. Meanwhile, the strategy for improving the environment externally is through increasing the role of parents/community, improving technology, and government policies.
\end{abstract}

Keywords : strategy, improvement, school environment 


\section{PENDAHULUAN}

Organisasi sekolah sebagai suatu sistem berarti organisasi sekolah tidak dapat lepas dari lingkungannya baik yang bersifat internal maupun eksternal. Lingkungan yang melingkupi organisasi sekolah dan memperngaruhi jalannya organisasi sekolah sifatnya selalu berubah. Organisasi merupakan sebagai pemberian struktur/susunan, terutama dalam penempatan personal, yang dihubungkan dengan garis kekuasaan dan tanggung jawabnya didalam keseluruhan organisasi (Purwanto, 2005:128)

Dibutuhkan strategi dalam upaya peningkatan lingkungan sekolah. Pengertian strategi adalah sebuah rencana yang komprehensif dan integratif yang dapat dijadikan pedoman dan pegangan dalam memenangkan persaingan dan kompetisi (Sagala, 2013)

Dalam pengertian lain, bahwa strategi adalah rencana yang menyeluruh dan komprehensif dalam mengintegrasikan segala sumber dan kapabilitas yang mempunyai tujuan yang panjang untuk memenangkan kompetensi. (Sagala, 2013). Menurut para ahli, strategi adalah alat bantu untuk mencapai sebuah tujuan organisasi atau perusahaan dalam rangka tujuan jangka panjang, program tindak lanjut, serta prioritas alokasi sumber daya. (Rangkuti, 2008)

Lingkungan berasal dari kata lingkung artinya "sekeliling, sekitar, selingkungan, seluruh suatu lingkaran, daerah dan sebagainya. (Hoetomo, 2015). Lingkungan sekolah merupakan jumlah benda hidup dan mati sertu seluruh kondisi yang ada di dalam ruang yang kita tempati (Supardi, 2003). Sedangkan pengertian lain bahwa lingkungan sekolah merupakan tempat bagi para siswa secara bersamasama belajar bersama rekan siswa lainnya secara terarah dalam menerima transfer pengetahuan dari guru yang di dalamnya mencakup keadaan sekolah dan sekitar sekolah, hubungan siswa dengan temantemannya, hubungan siswa dengan gurugurunya dan staf sekolah, kualitas guru dan metode mengajarnya, keadaan gedung, masyarakat sekolah, tata tertib, fasilitas sekolah serta sarana dan prasarana sekolah (Hamalik, 2003 : 131).

Lingkungan sekolah menjadi lingkungan anak berada dalam situasi belajar dan ini akan memberikan pengaruh terhadap tumbuh kembang kepribadian anak. Suasana lingkungan sekolah yang kondusif, nyaman, akan membentuk kedisiplinan belajar dan kedisiplinan sekolah. 
Lingkungan sekolah meliputi lingkungan fisik sekolah yang meliputi suasana dan prasarana belajar, sumber belakar dan media belajar. Kemudian lingkungan sosial, terkait hubungan siswa dengan siswa lainnya, guru-guru dan staf sekolah lainnya. Lingkungan akademis, terkait dengan suasana sekolah dan pelaksanaan kegiatan belajar mengajar dan berbagai kegiatan ekstrakurikuler (Surya, 2004)

Muhamad Surya mengemukakkan bahwa linkungan sekolah akan kondusif, jika lingkungan fisik, sosial maupun psikologis dapat menumbuhkan dan mengembangkan minat untuk bekerja dengan baik dan produktif. Perlu diciptakannya lingkungan fisik yang sebaik mungkin, seperti ruangan yang bersih, tata letak yang sesuai, fasilitas yang baik. Lingkungan sosial psikologis seperti kehidupan pribadi antar kepala sekolah, guru, staf, siswa dan wali murid mempunyai hubungan yang baik. Mempunyai kehidupan pribadi, kelompok kepemimpinan, pengawasan, bimbingan, promisi, kesempatan untuk maju dan ada rasa kekeluargaan (Surya, 2004).

SD Islam Al-Ikhlas merupakan satuan unit pendidikan dari Yayasan Masjid Al-Ikhlas. Sedangkan tujuan organisasi sekolah Yayasan Masjid AlIkhlas yang antara lain dapat hidup berkembang dengan cara memenuhi tuntutan lingkungan. Memenuhi tuntutan lingkungan berarti dapat memanfaatkan segala kesempatan dan atau tantangan/ancaman dari lingkungan yang komplek. Oleh karena itu sebagai konsekwensinya; organisasi sekolah Yayasan Masjid Al-Ikhlas (untuk selanjutnya disebut YMAI) harus melakukan berbagai kegiatan dalam rangka menghadapi atau memenuhi tuntutan perubahan-perubahan tersebut.

Yayasan Masjid Al-Ikhlas adalah salah satu lembaga pendidikan Islam yang menaungi KB/TK IslaM. SDI dan SMPI yang berdiri pada tahun 1967 bersamaan dengan berdirinya Taman Kanak-kanak (TK) Islam Al-Ikhlas. Sebagai kepala sekolah yang pertama adalah Drs. $\mathrm{H}$. Shadikin A.H. pendirian sekolah ini didasarkan oleh pengurus Yayasan Masjid Al-Ikhlas (YMAI) Cipete yang terus bergerak dalam meningkatkan sarana dan prasarana bagi dunia pendidikan. Pada awalnya hanya menampung satu lokal dengan jumlah siswa sebanyak 22 orang. Seiring dengan perkembangan waktu, SD Islam Al-Ikhlas mengalami peningkatan jumlah siswa hingga pada tahun ajaran 2005/2006 terdapat 24 kelas dengan jumlah siswa sebanyak 897 orang.

SD Islam Al-Ikhlas memiliki tata tertib yang sudah berjalan baik dengan sistem 
yang telah ditentukan dalam rapat gabungan TK, SD, dan SMP. Adapun teknisnya, baik guru, siswa dan karyawan tidak dibedakan. Ini berari bahwa tata tertib tersebut harus dijalankan dengan penuh tanggung jawab sesuai dengan pekerjaannya masing-masing, menjunjung tinggi kebersamaan, disiplin, serta perwujudan lingkungan tertib dan bersih. Lokasi SD Islam Al-Ikhlas cukup strategis, tidak terlalu dekat dengan keramaian lalu lintas, namun dapat ditempuh dari berbagai arah, sehingga mudah dijangkau

\section{METODE PENELITIAN}

Penelitian ini adalah pendekatan kualitatif. Jenis penelitian kualitatif merupakan penelitian untuk memahami segala fenomena tentang sesuatu yang dialami oleh subyek penelitian (Lexy J. Moeleng, 2014). Data dikumpulkan dalam bentuk kata-kata dan bukan angka, pendekatan tersebut adalah pendekatan kualitatif (Sudarwin Denim, 2002).

Sedangkan sumber data yang diperoleh yaitu data primer yang didapat langsung dari sumbernya langsung yaitu di Yayasan Masjid Al-Ikhlas (Soerjono Soekanto, 2003). Data yang diperoleh merupakan hasil dari pengamatan, wawancara dan dokumentasi di lapangan untuk penelitian.
Data diperoleh merupakan dari sekolah dasar Al-Ikhlas yang berupa data-data sekolah dan berbagai literatur yang relevan dengan pemahaman, dan data ini diberikan kepada pengumpul data melalui orang lain, sumber buku, dokumen pribadi, dokumen resmi sekolah, dan arsip.

Tehnik pengumpulan data dengan wawancara, observasi dan dokumentasi. Kemudian data-data tersebut dianalisis secara non statistik, yaitu penelitian yang dilakukan dengan menggambarkan data yang diperoleh dangan kata-kata atau kalimat yang dipisahkan dalam kategorikategori untuk memperoleh kesimpulan. (Lexy J. Moleong, 2014)

\section{HASIL DAN PEMBAHASAN}

Hasil penelitian menggambarkan temuan utama dari penelitian. Sajian dalam hasil dan pembahasan ditulis secara bersistem, hanya hasil data/ informasi yang terkait dengan tujuan penelitian. Pembahasan dalam artikel penelitian menjelaskan hasil yang didapat dari penelitian.

Penulis menyusun, menganalisis, mengevaluasi, menginterpretasi serta membandingkan hasil dari temuan terbaru dengan temuan penelitian yang telah ada. Penulis harus memperhatikan konsistensi artikel mulai dari judul hingga daftar pustaka. 
Tabel atau gambar yang ada, disajikan dengan penjelasan yang cukup dan dengan menyertakan nomor dan judul. Penulisan nomor dan judul tabel ditempatkan di atas tabel, sedangkan nomor dan judul gambar ditempatkan di bawah gambar. Lengkapi tabel dan gambar yang ada dengan menuliskan sumber di bawah masingmasing tabel/ gambar. Tabel dibuat tanpa border vertikal. Contoh tabel:

\section{Tabel 1 Lama Menekuni Bisnis Menggunakan Media Sosial Instagram}

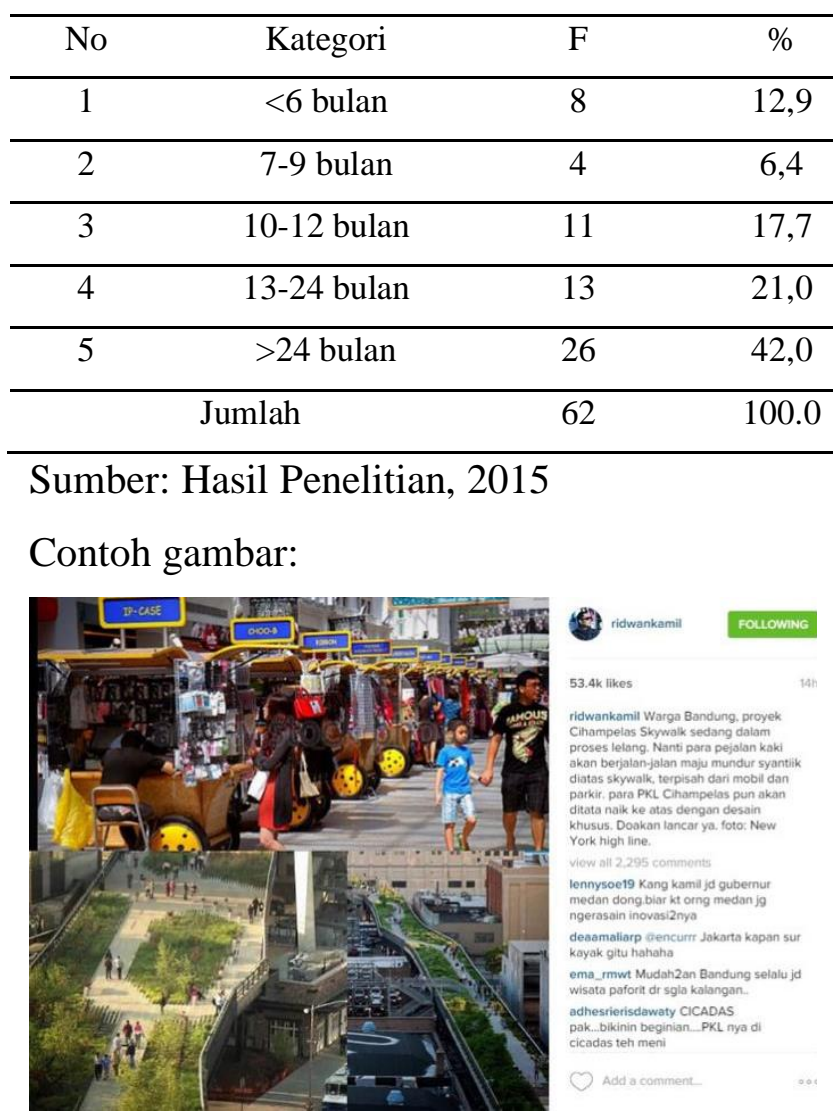

Sumber: Instagram, 2016

Gambar 1 Foto Unggahan Ridwan Kamil
Hindari penggunaan sub judul di bagian hasil dan pembahasan. Seluruh paparan hasil dan pembahasan di dalam artikel ditulis dalam bentuk esai, sehingga tidak ada format numerik atau abjad yang memisahkan antara bab/bagian, atau untuk menandai bab/bagian baru.

\section{Strategi Peningkatan Lingkungan Sekolah di Sekolah Dasar Islam Al- Ikhlas Jakarta Selatan}

Dalam peningkatan lingkungan sekolah yang dilakukan tentu tidak terlepas dari capaian visi dan misi sekolah, maka digunakan yang namanya strategi. Strategistrategi ini kalau dilihat di SD Islam AlIkhlas melalui penjabaran dan sosialisasi dalam workshop antara pihak sekolah dengan orang tua siswa, dan dipublikasikan di berbagai tempt dilingkungan SD Islam Al-Ikhlas melalui budaya sekolah atau yang lebih dikenal dengan "Budaya ALIX" yaitu nama popular dari Al-Ikhlas. Budaya Alix tersebut meliputi budaya senyum, salam , sapa , sopan, dan santun.

Strategi peningaktan lingkungan yang dilakukan oleh SD Islam Al-Ikhlas terbagi menjadi dua yaitu lingkungan internal dan lingkungan eksternal. Strategi dilingkungan internal meliputi : 


\section{Kepemimpinan}

Kelangsungan hidup dan keberhasilan organisasi pada masa kini, tergantung pada kemampuan pemimpin dalam mengantisispasi lingkungan eksternal dan internal. Dalam hal ini, organisasi harus memiliki pemimpin yang efektif dalam menjalankan manajemen untuk mengelola perubahan yang ada dan perbaikan yang berkelanjutan. Tantangan dari sebuah lembaga pendidikan khususnya SD Islam Al-Ikhlas adalah bagaimana menjadi pelopor perubahan lembaga pendidikan yang dipimpinnya.

Sesuai dengan perubahan paradigma usaha jasa pendidikan yang dikembangkan oleh Yayasan Masjid Al-Ikhlas (YMAI), maka kepala sekolah berfungsi sebagai manajer. Sebagai seorang manajer, maka dia harus menjalankan fungsi-fungsi manajerialnya, yaitu merencanakan, mengorganisasikan, menggerakkan (melaksanakan), dan mengontrol.

Dalam menjalankan kepemimpinannya, kepala SD Islam Al-Ikhlas menerapkan gaya kepemimpinan situasional, yaitu dengan melihat kondisi seperti apa yang sedang dihadapi. Usaha yang dilakukan kepala sekolah dalam memimpin SD Islam Al-Ikhlas, salah

satunya yaitu dengan melakukan supervise langsung ke lapangan ( Quality Insurance) juga dengan melibatkan pakar dari luar (konsultan pendidikan) yang berkaitan dengan kegiatan pengembangan peningkatan mutu sekolah.

\section{Sumber Daya Manusia (SDM)}

Dalam proses pengembangan sekolah, diperlukan tenaga-tenaga professional dalam bidangnya. Aplikasi yang ada dalam rangka pencapaian visi dan misi. Karena ini merupakan strategi dalam tataran praktis tidak bersifat teoritis, maka target/sasaran yang yang akan dicapai diantaranya : mewujudkan tenaga guru yang professional (ahli) dan visioner (mempunyai pandangan jauh kedepan), artinya bahwa jika guru SD Islam AlIkhlas sudah professional dan visioner maka yang terjadi adalah pembahasan bagaimana mengajar dengan baik. Sehingga, akan tersipta suasana kerja yang kondusif, dan menghasilkan mutu anak yang baik.

\begin{tabular}{lrr}
\multicolumn{1}{c}{ Kepala sekolah } & dalam \\
memberdayakan & guru & dan \\
karyawannya yaitu dilakukan & dengan \\
memberikan kesempatan & kepada \\
mereka untuk mengikuti berbagai \\
pelatihan, seminar, workshop, dan
\end{tabular}


sejenisnya. Pemberian reward bagi guru yang berprestasi dan menyediakan sarana pendukung dalam meningkatkan profesionalisme guru. Adapun namanama program pembinaan SDM di SD

Al-Ikhlas antara lain:

a. English Club For Teacher

b. Pelatihan KBK

c. Pelatihan Pembelajaran Tematik

d. Pelatihan Metode Qiro'ati

e. Pelatihan Komputer

f. Wisata Rohani

g. Studi Banding

h. Penyediaan Buku Referensi

i. Bedah Buku

j. Out bond

k. Rapat Pembinaan Guru

1. Pemilihan Guru Berprestasi

m. Pelatihan Guru Keluar

3. Kurikulum dan Kegiatan Belajar Mengajar (KBM)

Pengembangan dan inovasi kurikulum, merupakan langkahlangkah untuk meningkatkan mutu pendidikan. Dalam sasaran dan targernya, SD Islam Al-Ikhlas mempunyai beberapa point untuk dicapai, yaitu:

a. Terselenggaranya Pembelajaran Aktif, Inovatif, Kreatif, Efektif dan Menyenangkan atau disingkat menjadi PAIKEM. b. Unggul di bidang akademik, yang tergambar dari nilai ulangan harian, nilai raport, portofolio, dan ijazah bagi siswa kelas 6 yang telah mengikuti ujian.

c. Mampu bercakap-cakap dengan bahasa inggris. Point ke tiga ini adalah salah satu strategi untuk mencapai visi dari kata berwawasan global, yaitu melalui penguasaan bahasa, khususnya bahasa Inggris.

\section{Keuangan}

Salah satu kekuatan sebuah organisasi adalah kondisi keuangan yang baik. SD Islam Al-Ikhlas, secara fungsional tidak mempunyai otoritas penuh dalam pengelolaan keuangan. Dalam pengelolaan dan pembiayaan pendidikan diserahkan ke Yayasan Masjid Al-Ikhlas, seperti sistem penggajian, biaya pengadaan dan pemeliharaan sarana dan prasarana, dan lain sebagainya.

Strategi pembiayaan sekolah yang dilakukan SD Islam Al-ikhlas yaitu dengan pemberdayaan Badan (BP3) yang termasuk di dalamnya wakil orang tua kelas (WOTK). Keterlibatan BP3 dalam penyusunan Rancangan Anggaran Pendapatan dan Biaya Sekolah (RAPBS) serta dalam 
penyelenggaraan dana kegiatan siswa . penyusunan RAPBS dan laporan keuangan disajikan secara transparan dan akuntabel.

Sedangkan strategi peningkatan lingkungan sekolah yang dilakukan oleh SD Islam Al-Ikhlas secara eksternal meliputi :

\section{Orang Tua / Mayarakat}

Peran orang tua terhadap pengembangan SD Islam Al-Ikhlas tidak bias dipungkiri. Misalnya dalam proses pengambilan keputusan dan keterlibatannya dalam setiap kegiatan sekolah.

Hal ini menjadi sebuah peluang yang cukup menguntungkan bagi pihak sekolah untuk terus menanamkan kepercayaan kepada masyarakat setempat dengan memberikan pelayanan yang terbaik.

\section{Perkembangan Teknologi}

Perkembangan teknologi tidak terlepas dari ilmu pengetahuan dan teknologi (IPTEK). Ilmu pengetahuan menjadi dasar di dalam penciptaan teknologi baru sangat nyata dalam perkembangan dunia pendidikan. Lingkungan teknologi akan berganti setiap periode. Oleh karena itu, sumberdaya manusia (SDM) yang ada pada tingkatan sekolah perlu memahami perubahan tersebut.
Kemajuan teknologi dapat meningkatkan kualitas dan operasional sekolah.

Lembaga pendidikan SD Islam AlIkhlas cukup peka terhadap kemajuan dan perubahan teknologi, khususnya teknologi computer dan komunikasi. Pada masa sekarang ini, proses pencatatan system administrasi dan keuangan tidak lagi diproses secara manusal, tetapi sudah menggunakan sistem komputerisasi. Sekolah tersebut juga telah menggunakan telepon dan faximili sebagai alat komunikasi.

\section{Kebijakan Pemerintah}

Sama halnya dengan teknologi, isu kebijakan juga berpengaruh terhadap perkembangan pendidikan. Misalnya, kebijakan kurikulum yang ditetapkan oleh pemerintah. Pada saat ini, SD Islam Al-Ikhlas selalu mengikuti kurikulum yang berlaku sesuai dengan kebijakan pemerintah dalam bidang pendidikan dan tentunya disesuaikan dengan perkembangan zaman. Begitu juga dengan standar nilai yang diterapkan SD Islam Al-Ikhlas yang diberlakukan oleh pemerintah.

Sedangkan mengenai peta perubahan politik, tidak begitu berpengaruh terhadap pengembangan sekolah, hal ini mengingat karena 
sekolah tersebut merupakan sekolah yang berstatus swasta.

\section{SIMPULAN}

Strategi peningkatan lingkungan sekolah di SD Islam Al-Ikhlas sesuai dengan capaian visi dan misi sekolah. Semua strategi yang direncanakan disosialisasikan melalui bentuk-bentuk kegiatan seperti pelatihan, workshop, seminar dan lain sebagainya kepada seluruh pihak. Strategi peningkatan lingkungan sekolah di SD Islam Al-Ikhlas terbagi menjadi dua yaitu strategi lingkungan internal dan eksternal. Strategi peningkatan lingkungan internal di SD Islam Al-Ikhlas meliputi kepemimpinan dengan menjalankan manajemen dalam setiap perubahan dan perbaikan yang berkelanjutan. Peningkatan sumber daya manusia (SDM) sehingga menjadi guru yang profesional. Kurikulum dan kegiatan belajar mengajar (KBM) dalam meningkatkan mutu pendidikan. Pengelolaan keuangan dengan memberdayaan BP3 dalam penyusunan Rancangan Anggaran Pendapatan dan Biaya Sekolah (RAPBS) serta dalam penyelenggaraan dana kegiatan siswa. penyusunan RAPBS dan laporan keuangan disajikan secara transparan dan akuntabel. Sedangkan Strategi peningkatan lingkungan sekolah meliputi peran orang tua dalam mengembangkan SD Islam AlIkhlas. Memahami perkembangan teknologi dan meningkatkan kualias dan operasional sekolah. Kebijakan pemerintah, saat ini SD Islam Al-Ikhlas selalu mengikuti sesuai kebijakan pemerintah dalam bidang pendidikan dan lainnya.

\section{DAFTAR PUSTAKA}

Darwin Denim. Menjadi Peneliti Kualitatif, Rancangan Metodologi, Presentasi dan Publikasi Hasil Penelitian Untuk Mahasiswa dan Penelitian Pemula Bidang Ilmu Sosial, Pendidikan dan Humamiora. Cet 1, Bandung: Pustaka Setia.

Hamalik, Oemar. (2003). Proses Belajar Mengajar. Jakarta : PT. Bumi Aksara.

Hoetomo. (2005). Kamus Lengkap Bahasa Indonesia. Surabaya: Mitra pelajar

Muhammad Surya. (2004). Psikologi Pendidikan. Dirjen Dikdasmen: Direktorat Kependidikan.

Moeleng J. Lexy (2014). Metodologi Penelitian Kualitatif. Bandung: Remaja Rosdakarya.

Purwanto, M, Ngalim. (2005). Administrasi dan Supervisi Pendidikan. Bandung: PT Remaja Rosda Karya

Rangkuti, F. (2013). Analisis SWOT. Jakarta: PT Gramedia

Sagala, S. (2013). Manajemen Strategik dalam Peningkatan Mutu Pendidikan. Bandung: Alfabeta,CV

Supardi, Imam, 920030 "Lingkungan Hidup dan Kelestariannya", Bandumg : PT Alumni 